\title{
Heterospecific pollen deposition among plants sharing hummingbird pollinators in the Brazilian Atlantic Forest
}

\author{
Lorena Coutinho Nery da Fonseca ${ }^{1}$, André Rodrigo Rech ${ }^{2,6}$, Pedro Joaquim Bergamo ${ }^{3,4}$, Vania Gonçalves- \\ Esteves $^{5}$ \& Marlies Sazima ${ }^{1,3}$
}

\begin{abstract}
Hummingbirds are the most important group of pollinating birds in the Neotropics and tend to use, concomitantly, more than one plant species as food source. Pollen may be mixed on hummingbirds' body due to the visits to different plant species; therefore, these birds may promote heterospecific pollen deposition (HPD). The hummingbirds potential to promote HPD, the occurrence of HPD and its implications in plant reproduction are scarcely known in the Atlantic Forest. We have studied the transport of pollen by three hummingbird species from the Brazilian Atlantic Forest. We have also checked the actual HPD occurrence under natural conditions in two plant species, namely Canistropsis seidelii and Psychotria nuda. Moreover, we investigated Nidularium innocentii reproductive system evaluating the effect of HPD on its reproduction by simulating a pollen mixture pollination. We found hummingbirds transporting heterospecific pollen mixtures on their bodies, which in turn were deposited onto stigmas of different species. We have also found that mixed pollen deposition had negative effect on the fitness of $N$. innocentii. We conclude that hummingbirds carry pollen mixtures at the same body parts, leading to potential HPD at the community level. Moreover, hummingbird-plant communities in the Atlantic Rainforest show remarkable similarities in temporal organization and interaction pattern. This suggests that HPD may be a widespread phenomena in these communities.
\end{abstract}

Key words: competition for pollination, fruit/seed set, pollen placement, pollen load, pollinator sharing, reproductive success.

\section{Resumo}

Beija-flores são o grupo de aves polinizadoras mais importantes nos Neotrópicos e tendem a utilizar, concomitantemente, mais de uma espécie de planta como fonte de alimento. O pólen pode estar misturado no corpo dos beija-flores devido às visitas em diferentes espécies de plantas, portanto, essas aves podem promover deposição de pólen heterospecífico (DPH). O potencial dos beija-flores em promover DPH, a ocorrência de DPH e suas consequências na reprodução das plantas são pouco conhecidas na Mata Atlântica. Nós estudamos o transporte de pólen por três espécies de beija-flores da Mata Atlântica brasileira. Nós também verificamos a ocorrência de DPH em condições naturais em duas espécies de planta, Canistropsis seidelii e Psychotria nuda. Além disso, nós investigamos o sistema reprodutivo de Nidularium innocentii, avaliando o efeito de DPH em sua reprodução ao simular uma polinização com mistura de pólen. Nós encontramos beija-flores transportando misturas de pólen heterospecífico em seus corpos, que por sua vez foram depositados nos estigmas de diferentes espécies. Nós também encontramos que a deposição de mistura de pólen tem um efeito negativo na aptidão de $N$. innocentii. Nós concluimos que beija-flores carregam misturas de pólen na mesma região do corpo, levando a um potencial DPH ao nível da comunidade. Além disso, comunidades de plantas e beija-flores na Floresta Atlântica exibem diversas similaridades em sua organização temporal e padrão de interações. Isso sugere que DPH pode ser um fenômeno difundido nestas comunidades.

Palavras-chave: competição pela polinização, produção de frutos/sementes, deposição de pólen, carga polínica, compartilhamento de polinizadores, sucesso reprodutivo.

\footnotetext{
${ }^{1}$ Universidade Estadual de Campinas, Programa de Pós-graduação em Biologia Vegetal, Inst. Biologia, C.P. 6109, 13083-970, Campinas, SP, Brasil.

${ }^{2}$ Universidade Federal dos Vales do Jequitinhonha e Mucuri, Curso de Licenciatura em Educação do Campo, Campus JK, Rod. MGT 367, Km 583, 5000, Alto da Jacuba, 39100-000, Diamantina, MG, Brasil.

${ }^{3}$ Universidade Estadual de Campinas, Depto. Biologia Vegetal, Inst. Biologia, C.P. 6109, 13083-970, Campinas, SP, Brasil.

${ }^{4}$ Universidade Estadual de Campinas, Programa de Pós-graduação em Ecologia, Inst. Biologia, C.P. 6109, 13083-970, Campinas, SP, Brasil.

${ }^{5}$ Museu Nacional do Rio de Janeiro, Lab. Palinologia, Horto Botânico, Quinta da Boa Vista, São Cristóvão, 20940-040, Rio de Janeiro, RJ, Brasil.

${ }^{6}$ Author for correspondence: andrerodrigorech@gmail.com
} 


\section{Introduction}

Plant and pollinators have been studied in the context of ecology and evolution of mutualistic relationships since the Sprengel's era (Waser \& Ollerton 2006; Willmer 2011, Rech \& Westerkamp 2014). When they co-occur, plant species sharing pollinators may compete via heterospecific pollen deposition (HPD) (Morales \& Traveset 2008; Mitchell et al. 2009; Ashman \& Arceo-Gómez 2013). At the community level, HPD magnitude depends on the number of interspecific switches by a given pollinator (Jakobsson et al. 2008). Among pollinator groups, hummingbirds are known to perform species-indiscriminate foraging bouts, increasing the potential of these visitors to promote HPD (Rathcke 1983). Hence, lesser is known about synchronopatric groups of plants used by hummingbirds as food source and how these plants interact with each other when sharing visitors.

Hummingbirds (Trochilidae) are important pollinators of a large array of Neotropical plants (Machado \& Semir 2006; Rocca-de-Andrade 2006; Vizentin-Bugoni et al. 2014), with highlight to the sub-family Phaethornithinae in the Brazilian Atlantic Forest (Sazima et al. 1995,1996; Buzato et al. 2000; Wendt et al. 2008). Among the Phaethornithinae, Ramphodon naevius is indicated as the main pollinating bird from the lowland Atlantic Forest (Sazima et al. 1995; Buzato et al. 2000; Wendt et al. 2008). Ramphodon naevius individuals visit several plant species in one day, visiting up to four different species during a single foraging bout (Sazima et al. 1995). Therefore, many plant species share $R$. naevius as pollinator and may potentially receive heterospecific pollen from these visitors. The knowledge on how these birds interact with plants is an important contribution to understand the ecology of plant-plant interactions mediated by pollinators in the Atlantic Forest.

Experimental evidence highlighted the species-indiscriminate foraging behaviour of hummingbirds promoting pollen wastage on heterospecific stigmas (Feinsinger et al. 1988; Feinsinger \& Tiebout 1991). Moreover, hummingbird-pollinated communities are supposed to exhibit staggered flowering phenologies as a result of competitive interactions among shared pollinators (Stiles 1976; Aizen \& Vázquez 2006). Depositing pollen on different parts of the shared pollinators is another possible solution to gain the facilitation benefit provided by a larger number of co-flowering species, thus potentially avoiding the negative consequence of heterospecific pollen deposition (Muchhala \& Potts 2007; Ramírez et al. 2011). This strategy was already recorded among Dicliptera squarrosa Nees, Ruellia brevifolia (Pohl) C. Ezcurra, Cuphea melvilla Lindl. and Manettia cordifolia Mart., a group of plants sharing Phaethornis pretrei (Lesson \& Delattre 1839) as their main pollinating hummingbird (Araújo 2010).

The reduced number of studies analysing pollen grains on hummingbirds' body are more focused on the trophic aspect than on the discussion about their potential for interspecific pollen transfer (Brown \& Kodric-Brown 1979; Amaya-Márquez et al. 2001; Borgella Jr. et al. 2001; Lasprilla 2003; Almeida 2005; Rodrigues-Flores \& Stiles 2005; Araujo 2010). Among the studies actually focused on interspecific pollen transfer, Brown \& KodricBrown (1979) found that hummingbirds do deposit heterospecific pollen and that they deposited more heterospecific than conspecific pollen onto the stigmas in approximately $20 \%$ of the visits. Therefore, although it seems to be an appealing solution when sharing pollinators, the prevalence of pollen segregation on the pollinators' bodies clearly deserves further studies.

Here we describe the pollen found on three hummingbird species in the lowland Atlantic Forest of Southeastern Brazil and the potential of pollen mixture on their bodies. We used a synchronopatric pair of species (Canistropsis seidelii (L.B.Sm. \& Reitz) Leme, (Bromeliaceae) and Psychotria nuda (Cham. \& Schltdl.) Wawra, (Rubiaceae) and counted the pollen exchanged between them to have a quantitative evidence of the heterospecific pollen deposition (HPD). Finally, the pollen from two species was manually mixed and deposited on Nidularium innocentii Lem. (Bromeliaceae) stigmas to measure the potential impact of pollen mixture and its effect on reproduction through the fruit set.

\section{Material and Methods}

We conducted this study at Núcleo Picinguaba in Parque Estadual da Serra do Mar (PESM), Southeastern Brazil (São Paulo - latitude $23^{\circ} 20^{\prime} 03^{\prime \prime} \mathrm{S}$ and longitude $\left.44^{\circ} 49^{\prime} 56^{\prime \prime} \mathrm{W}\right)$. The climate at the region is categorized as tropical wet with mean annual temperature above $18{ }^{\circ} \mathrm{C}$ and precipitation of approximately $2200 \mathrm{~mm}$ (Sanchez et al. 1999). The vegetation in the area is mainly Dense Ombrophilous Atlantic Forest (Veloso \& Góes-Filho 1982). 
Pollen collection and preparation

We captured the birds from November 2007 to October 2008 using mist nets $(12 \times 3$ meters and $18 \mathrm{~mm}$ mesh). Over three days (every month), from 6:00 a.m. to 12:00 p.m., we mounted three mist nets in the understory and three in the subcanopy of trees (between eight and 15 meters high). All mist nets were monitored during the whole capture session. We removed the hummingbirds from the net immediately after they were caught and removed the pollen from their bodies using transparent adhesive tape by specifying each of the touched parts (top head, forehead, throat and bill: superior and inferior base and tip parts - Fig. 1a) (Kearns \& Inouye 1993; Borgella Jr. et al. 2001). Subsequently, we attached the tape to a slide in order to analyse it under optical microscopy. We identified the birds according to a field guide (Sigrist 2007), ringed them with specific marking bands provided by CEMAVE/IBAMA and later have released them. We have identified or separated the pollen grains in morphotypes according to a plant pollen library from the same region, which was built during the study. Slides containing less than 10 pollen grains were discharged to avoid contamination counting. In total, we captured 34 hummingbirds and analysed the pollen samples: 27 from Ramphodon naevius, four from Thalurania glaucopis and three from Florisuga fusca.

\section{Heterospecific pollen deposition} (HPD) under natural conditions

We used two plant species (Canistropsis seidelii and Psychotria nuda), already known as pollinated by hummingbirds (Sazima et al. 1995; Buzato et al. 2000; Mendonça \& Anjos 2003; Rocca-de-Andrade 2006), to quantify the HDP. Canistropsis seidelii is a herb with white tubular flowers surrounded by yellow bracts (Fig. 1d) and its anthers form a ring around the ellipsoid stigma, both at the same height (Leme 1998). Psychotria nuda is a distilic branched treelet with terminal yellow flowers surrounded by a red calyx with the anthers also in circle (Castro \& Araújo 2004; Corrêa 2011, Fig. 1f). Both species deposit their pollen around the hummingbirds' bill due to the circular organization and similar height of the stamens (C. seidelii $21.81 \pm 0.96 \mathrm{~mm}$ and $P$. nuda $17.10 \pm 2.08 \mathrm{~mm}$ - thrum flowers).

Besides observing the sharing of pollinators, we also collected information on the following nectar features: sugar concentration and volume, using a handheld refractometer and a microsyringe, respectively. We measured flowers at the end of anthesis from previously bagged floral buds, in order to assess nectar total volume and concentration. We calculated the sugar mass as the product of sugar concentration and volume. We also followed flowering phenology over two years to make sure that both monitored species were temporally able to exchange pollen (2008 and 2009). A trail of 500 meters (five meters each side) was travelled every month to count flowers and individuals covering the total area of $5000 \mathrm{~m}^{2}$. Parameters of nectar characterization (volume, sugar concentration and mass) were compared using $t$ tests.

During the flower overlapping periods, we collected 38 stigmas from $C$. seidelii and 31 from $P$. nuda, from flowers naturally exposed to visitors in order to quantify the HPD in situ. We then observed all stigmas under light microscopy for HDP quantification (Kearns \& Inouye 1993; Moragues $\&$ Traveset 2005). We analysed the differences between the total abundance of heterospecific pollen grains deposited on $P$. nuda and $C$. seidelli stigmas and the abundance of pollen grains from the receptor species using $t$ tests.

\section{Pollen mixture experiment}

We chose the most frequent species from the pollen samples found on the hummingbird bodies (Nidularium innocentii, Fig. 1e) to test the possible effects of pollen mixtures on fruit and seed set (Canela \& Sazima 2003; Moragues \& Traveset 2005). We then chose a second bromeliad species, Nidularium angustifolium Ule, in this experiment as pollen donor and its pollen was mixed with the pollen from the former species. Both species are synchronopatric and had their pollen placed onto the same part of the hummingbirds' bodies. Four tests were performed in $N$. innocentii flowers: spontaneous self-pollination $(\mathrm{n}=35)$, crosspollination using only $N$. innocentii pollen $(\mathrm{n}=$ 28 ), mixed pollination (1:1 pollen from other $N$. innocentii and $N$. angustifolium individuals) $(\mathrm{n}=$ $30)$ and natural pollination $(n=34)$. We considered the fruit set percentage as the result. Here we present just the mean seed set per treatment, since it was only possible to count seeds in a few experimental fruit. It was not possible to perform a statistical test using the seed set because several flowers that received the mixed pollination treatment did not develop into fruit. Therefore, we had treatments with discrepant sampling, preventing us from statistical comparisons. 

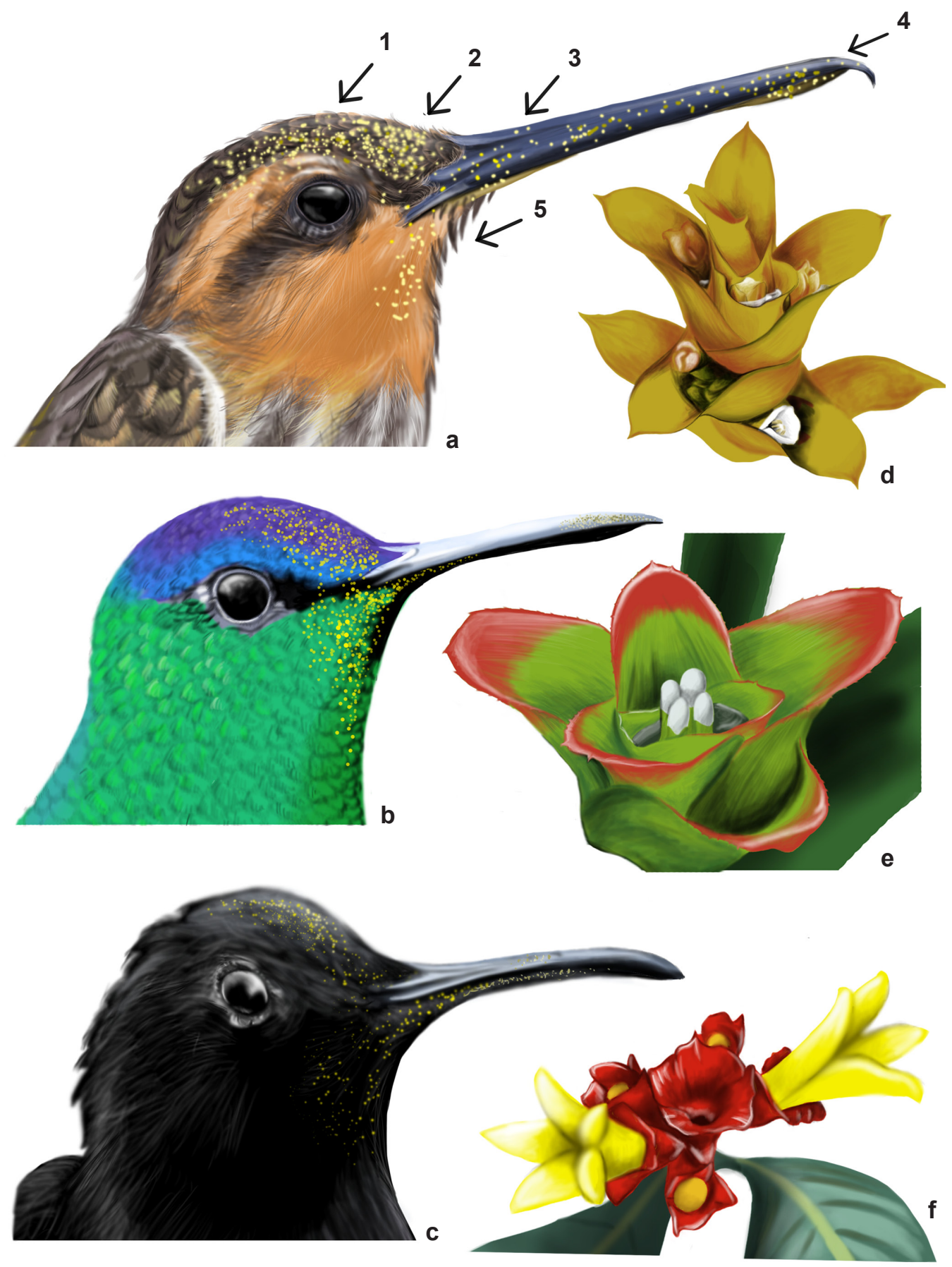

Figure 1 - Hummingbird and plant species taken under consideration in the current study. The intensity of yellow dots refers to the number of pollen grains found on each part of - a. Ramphodon naevius; b. Florisuga fusca; c. Thalurania glaucopis body. Figure a. is showing the sites in the hummingbird head where the pollen was collected from - 1. top head; 2. forehead; 3. base; 4. tip parts of superior bill (pollen from sites 3 and 4 were also collected from the inferior bill); 5. throat. The three herein represented plant species are those taken under consideration in the performed experiments - d. Canistropsis seidelli; e. Nidularium innocentii; f. Psychotria nuda. Illustrations by Raoni Rebouças. 
Table 1 - Pollen types found on the body of hummingbirds captured at the lowland Atlantic Forest of Serra do Mar State Park in São Paulo. The column "Individuals" refers to the number of captured individuals carrying each pollen type.

\begin{tabular}{|c|c|c|}
\hline Pollen Type & Hummingbird & Individuals (n) \\
\hline \multicolumn{3}{|l|}{ Bromeliaceae } \\
\hline Billbergia pyramidalis (Sims) Lindl. & Ramphodon naevius (Dumont) & 1 \\
\hline Bromeliaceae sp. 1 & Ramphodon naevius & 1 \\
\hline Bromeliaceae sp. 2 & Ramphodon naevius & 5 \\
\hline Bromeliaceae sp. 3 & Ramphodon naevius & 1 \\
\hline Bromeliaceae sp. 4 & Ramphodon naevius & 3 \\
\hline Canistropsis seidelii (L.B.Sm. \& Reitz) Leme & Ramphodon naevius & 1 \\
\hline Neoregelia johannis (Carrièrre) L.B.Sm. & Ramphodon naevius & 3 \\
\hline Nidularium angustifolium Ule & Ramphodon naevius & 5 \\
\hline Nidularium innocentii Lem. & $\begin{array}{l}\text { Ramphodon naevius, } \\
\text { Florisuga fusca (Vieillot) }\end{array}$ & $\begin{array}{c}10 \\
2\end{array}$ \\
\hline Quesnelia arvensis (Vell.) Mez & Ramphodon naevius & 5 \\
\hline Tillandsia sp. 1 & Ramphodon naevius & 3 \\
\hline Vriesea sp. 1 & $\begin{array}{l}\text { Ramphodon naevius } \\
\text { Thalurania glaucopis (Gmelin) }\end{array}$ & $\begin{array}{l}2 \\
1\end{array}$ \\
\hline Vriesea sp. 2 & $\begin{array}{l}\text { Ramphodon naevius } \\
\text { Thalurania glaucopis }\end{array}$ & $\begin{array}{l}3 \\
1\end{array}$ \\
\hline \multicolumn{3}{|l|}{ Fabaceae } \\
\hline Dahlstedtia pinnata (Benth.) Malme & Ramphodon naevius & 1 \\
\hline Inga sp. & $\begin{array}{l}\text { Ramphodon naevius } \\
\text { Thalurania glaucopis } \\
\text { Florisuga fusca }\end{array}$ & $\begin{array}{l}2 \\
1 \\
1\end{array}$ \\
\hline \multicolumn{3}{|l|}{ Gesneriaceae } \\
\hline Besleria longimucronata Hoehne & Ramphodon naevius & 2 \\
\hline Nematanthus sp. 1 & Ramphodon naevius & 2 \\
\hline Nematanthus sp. 2 & $\begin{array}{l}\text { Ramphodon naevius } \\
\text { Thalurania glaucopis }\end{array}$ & $\begin{array}{l}2 \\
1\end{array}$ \\
\hline \multicolumn{3}{|l|}{ Heliconiaceae } \\
\hline Heliconia angusta Vell. & Ramphodon naevius & 3 \\
\hline \multicolumn{3}{|l|}{ Loranthaceae } \\
\hline Psittacanthus dichroos (Mart.) Mart. & Florisuga fusca & 1 \\
\hline \multicolumn{3}{|l|}{ Rubiaceae } \\
\hline Psychotria brachypoda (Müll. Arg.) Britton & Ramphodon naevius & 2 \\
\hline Psychotria nuda (Cham. \& Schltdl.) \& Wawra & $\begin{array}{l}\text { Ramphodon naevius } \\
\text { Thalurania glaucopis }\end{array}$ & $\begin{array}{l}3 \\
1\end{array}$ \\
\hline \multicolumn{3}{|l|}{ No identification } \\
\hline type \# 1 & Ramphodon naevius & 2 \\
\hline type \# 2 & Florisuga fusca & 1 \\
\hline type \# 3 & $\begin{array}{l}\text { Ramphodon naevius } \\
\text { Thalurania glaucopis }\end{array}$ & $\begin{array}{l}5 \\
1\end{array}$ \\
\hline
\end{tabular}




\begin{tabular}{llc}
\hline Pollen Type & Hummingbird & Individuals (n) \\
\hline type \# 4 & Ramphodon naevius & 2 \\
type \# 5 & Ramphodon naevius & 1 \\
type \# 6 & Ramphodon naevius & 1 \\
type \# 7 & Ramphodon naevius & 2 \\
type \# 8 & Ramphodon naevius & 3 \\
type \# 9 & Ramphodon naevius & 1 \\
\hline
\end{tabular}

\section{Results}

1. Transported pollen grains

We found 31 pollen types on the hummingbirds' bodies from six plant families (Tab. 1). Considering each hummingbird species we found twentynine pollen types on Ramphodon naevius, six on Thalurania glaucopis and four on Florisuga fusca. Bromeliaceae was the richest family in number of pollen species recorded in the hummingbirds' bodies: seven out of the 10 most frequent species (in number of hummingbird individuals carrying its pollen) belong to this family (Tab. 1). We found Bromeliaceae pollen grains more frequently onto the birds' head and the superior part of the bill.
All samples collected from $R$. naevius had pollen. Although greatly different among samples, the forehead and the superior bill base of $R$. naevius were the sites with bigger amounts of pollen grains (Fig. 1a). Both T. glaucopis and F. fusca did not have pollen on the base of their superior bill (Fig. 1 b,c). Moreover, T. glaucopis also did not have pollen on its inferior bill tip as it happened for the superior bill tip of F. fusca (Tab. 2).

Most birds (22 out of 34) had more than one pollen type with maximum of six types in a single sample. Twenty-one animals had mixed pollen types on the same body part. Females of Ramphodon naevius transported between one and four pollen

Table 2 - Number of samples containing pollen grains in each body part for each hummingbird species.

\begin{tabular}{llc}
\hline Body part & Hummingbird & Samples (n) \\
\hline Forehead and front head & Ramphodon naevius & 18 \\
& Thalurania glaucopis & 2 \\
\multirow{3}{*}{ Base of the superior bill } & Florisuga fusca & 2 \\
& Ramphodon naevius & 23 \\
& Thalurania glaucopis & 0 \\
Tip of the superior bill & Florisuga fusca & 0 \\
& Ramphodon naevius & 11 \\
Throat & Thalurania glaucopis & 3 \\
& Florisuga fusca & 0 \\
& Ramphodon naevius & 16 \\
Base of the inferior bill & Thalurania glaucopis & 4 \\
& Florisuga fusca & 1 \\
& Ramphodon naevius & 19 \\
Tip of the inferior bill & Thalurania glaucopis & 2 \\
& Florisuga fusca & 2 \\
& Ramphodon naevius & 11 \\
& Thalurania glaucopis & 0 \\
& Florisuga fusca & 1 \\
\hline
\end{tabular}


types and males between one and six types on their bodies. Florisuga fusca individuals transported only one type in each capture. Although pollen mixtures were frequent, we found a pronounced pollen dominance on some hummingbird body parts. Ninety-six percent $(96 \%)$ of the pollen mixtures we found on $R$. naevius' top head had one pollen type representing more than $50 \%$ of the grains, the same occurred in $87 \%$ of the samples from the forehead of the same species.

\section{HPD verification}

Nectar sugar concentration was higher in Psychotria nuda (21.31 vs. 14.86, $\mathrm{p}=0$,014) while nectar volume was higher in Canistropsis seidelli (25.92 vs. 18.83, p < 0,001) whereas the sugar mass was the same for both species (4.45 vs. 4.45, $\mathrm{p}=0.992)$. The two species monitored for HPD overlapped their flowering periods during four months in 2008 (C. seidelii flowered from March to August and P. nuda from March to June) and three months in 2009 (C. seidelii flowered from May to September and $P$. nuda from March to July). Apart from June and July 2009, P. nuda had always more flowers than $C$. seidelii. In 2008, the flowering peak (number of flowers) of both species occurred in April (134 flowers in P. nuda vs. 12 in C. seidelii), whereas in 2009, P. nuda peaked in April (219 flowers) and $C$. seidelii in June (21 flowers). We recorded visits from $R$. naevius, $T$. glaucopis and $P$. ruber to both plant species when monitoring its phenology. In addition to birds, $C$. seidelii was also visited by bee species of Euglossini and Trigona and $P$. nuda was visited by species of Trigona bees and butterflies. We recorded hummingbird movements between the two plant species during field walks.

We recorded slightly more $P$. nuda stigmas with heterospecific pollen $(n=38$ out of 58 analyzed stigmas) than $C$. seidelii ( $\mathrm{n}=34$ out of 62 analyzed stigmas). Among the analyzed $P$. nuda stigmas, $66 \%$ had heterospecific pollen and $46 \%$ had $C$. seidelii pollen. Regarding C. seidelii, 55\% of the stigmas had heterospecific pollen and only $24 \%$ of the total stigmas had $P$. nuda pollen. The abundance of heterospecific grains deposited on each species was similar in both studied species (9.02 \pm 21.16 on $P$. nuda vs. $5.21 \pm 17.52$ on $C$. seidelii $\left.\mathrm{t}_{(1,119)}=-1.07, \mathrm{p}=0.29\right)$. When accounting just the interference between these two species, $P$. nuda had more $C$. seidelli pollen grains deposited on its stigmas than the other way around $(6.31 \pm 17.32$ on $P$. nuda vs. $\left.1.05 \pm 2.84, \mathrm{t}_{(1,119)}=-2.29, \mathrm{p}=0.03\right)$.
3. Pollen mixture experiment in Nidularium innocentii

We found a difference in fruit set among pollination treatments in Nidularium innocentii. Fruit set was twice higher in intraspecific pollination (17 fruits from 28 flowers - 60.7\%) than it was in pollen mixture pollination (11 fruits from 30 flowers - 36.7\%). We found spontaneous self-pollination in just 2 fruits from 35 flowers (5.7\%) and the fruit set under natural condition was lower ( 9 fruits from 34 flowers - 26.5\%) than that in pollen mixture pollination. There was a trend of higher seed set in intraspecific pollination (869.5 mean seeds per fruit, $n=14$ ) than in other treatments. Seed set was similar between pollen mixture pollination $(n=4$, 495 mean seeds per fruit) and natural conditions (n $=25,581.72$ mean seeds per fruit).

\section{Discussion}

Our results show that hummingbirds from the Atlantic Forest community studied usually transport pollen loads from more than one plant species on their bodies. One pollen type usually dominated the body site of the hummingbird where it was deposited on. Moreover, pollen dominance was not enough to prevent heterospecific pollen deposition (HPD) as described in Psychotria nuda and Canistropsis seidelii. We also found that HPD had negative effect on Nidularium innocentii reproduction by reducing its fruit and seed set. Next items discusses each result in detail.

\section{Transported pollen grains}

The high amount of bromeliad pollen is a consequence of the high prevalence of this family as food source to hummingbirds in the Atlantic Forest (Buzato et al. 2000; Machado \& Semir 2006; Wolowski et al. 2013; Vizentin-Bugoni et al. 2014), contrasting with other biomes such as Cerrado or other tropical forests (Amaya-Márquez et al. 2001; Borgella Jr. et al. 2001; Lasprilla 2003; Araújo et al. 2013). For instance, pollen of only two bromeliad species, among other 29 plant species, were found on the body of hummingbirds in Colombian Amazon (Lasprilla 2003). The high number of bromeliads used by Ramphodon naevius also reinforces the already indicated importance of these plants as food sources to this bird (Buzato et al. 2000; Machado \& Semir 2006).

Great variation in the number of pollen grains transported by each bird species and even among individuals from the same species is a trend already reported in Phaethornis pretrei 
(Phaethornithinae) from Cerrado (Araújo 2010) and in some hummingbird species from the Amazon forest (Lasprilla 2003). This result draws attention to the interindividual variation within a species, fact that may potentially drive different individuals from the same species to have contrasting roles in plant reproduction. The interindividual differences may also reflect different animal capture times or different nectar-collecting behaviour by hummingbird individuals. For instance, $R$. naevius exhibits interindividual variation on foraging behaviour and floral choices throughout the day (Sazima et al. 1995). Therefore, captures from early morning or from thieving behaviour should cause animals to have less pollen onto their bodies. The concentrated pollen deposition onto the birds' top head, forehead and the superior base of the bill is a trend corroborated by the herein presented results. This pattern could reflect similar flower morphology between the hummingbird-pollinated species in this community (Bergamo et al. in prep.). It is also expected due to the hummingbirds' difficulties in cleaning the pollen deposited on these parts (Lasprilla 2003; Araújo 2010).

In two thirds of the captures, $R$. naevius carried similar number of mixed pollen types as already recorded in other long-billed species, such as Phaethornis guy (6 pollen types, Borgella Jr. et al. 2001) and P. pretrei (10 pollen types, Araújo 2010). Moreover, it is worth mentioning that $R$. naevius transported pollen from a single species in $30 \%$ of the captures. This indication of floral fidelity should be taken under consideration, especially regarding the foraging behaviour of this hummingbird species (Sazima et al. 1995). Although it usually forages in trap-lines by visiting different species, $R$. naevius spent certain amount of time on an exclusive species, a pattern corroborated by the herein presented results for the same locality but using an independent and different source of data. The pollen mixture dominance by one plant species may reiterate the hummingbird habit of choosing one main species and also getting some nectar from others (Henderson et al. 2001) or may just be a consequence of the resource abundance in the area (Justino et al. 2011), an issue for further studies.

This complex foraging behaviour exhibited by $R$. naevius should strongly impact the reproductive ecology of the plants it uses as food source. Moreover, pollen grains were usually mixed onto the same body part, suggesting that hummingbirds use more than one nectar source and that HPD may be widespread in this community. We therefore did not find a strategy of different pollen placement on hummingbird bodies as, previously reported on a Cerrado community (Araújo 2010). Therefore, it indicates that in this community the facilitation benefit of flowering together seems to compensate the cost of HPD (Morales \& Traveset 2008). Moreover, the generalism of this pattern in hummingbird-pollinated communities from the Atlantic rainforest still needs to be tested.

\section{HPD verification}

Our results show large variation in Psychotria $n u d a$ and Canistropsis seidelii total flowering period between the two years observed. We therefore, indicate different space-time scenarios for HPD between this two particular species, a result also supported by other studies (Almeida \& Alves 2000; Buzato et al. 2000; Castro \& Araújo 2004; Soares 2011). Despite the differences in the total flowering periods, all the literature records $P$. nuda flowering peak in April (Almeida \& Alves 2000; Castro \& Araújo 2004; Soares 2011). Similar to the herein found results from $C$. seidelii and $P$. nuda, another study using three hummingbirdpollinated species (Penstemon barbatus, Castilleja integra and Ipomopsis aggregata) found similar HPD level (respectively 49\%, 64\% and 57\%) (Brown \& Kodric-Brown 1979). Hence, 50\% HPD is normally detrimental to plant reproduction and it seems to be the cost of co-flowering, which should be compensated by the benefits of flowering at the same time (Ashman \& Arceo-Gómez 2013). Moreover, both species offered a similar amount of sugar mass despite showing nectar with contrasting volume and concentration indicating a similar energetic gain for the visitors of the two species.

\section{Pollen mixture experiment in} Nidularium innocentii

In the Nidularium innocentii pollination experiment we showed that this species is pollinator-dependent, since only one flower of the autonomous self-pollination set a fruit. The fruit set differed between intraspecific cross-pollination and pollen mixture deposition, showing that HPD probably works on the fruit set level. At this level, it was previously reported that pre-zigotic barriers are not good to prevent hybridization in bromeliads (Vervaeke et al. 2001; Wendt et al. 2008). However, the reproductive isolation seems to be corroborated by the scarcity of hybrids under natural conditions, which fits our findings (Vervaeke et al. 2001; 
Wendt et al. 2008). The trend of smaller seed set under mixed pollen deposition was also reported in herb species pollinated by bees, flies and beetles (Galen \& Gregory 1989; Brown \& Mitchell 2001; Moragues \& Traveset 2005; Ashman \& ArceoGómez 2013). Meanwhile, it is worth to mention that HPD is not always a problem for plant reproduction, depending on its magnitude and the plant species attributes (Morales \& Traveset 2008).

\section{Conclusion}

In the studied community, Atlantic Forest hummingbirds tend to transport more than one pollen type on their bodies, they actually transfer this pollen among species and the transference has negative impact on seed set for at least one species. Hummingbird-plant communities in the Atlantic Rainforest show remarkable similarities in temporal organization, interaction pattern and in hummingbird and plant attributes (Sazima et al. 1996; Buzato et al. 2000; Rocca-de-Andrade 2006; Vizentin-Bugoni et al. 2014). This suggests that HPD may be a widespread phenomena in these communities, a trend to be confirmed with future studies. Among the pollen carried by hummingbirds, one was usually dominant and this fact should reduce the interference among species. Moreover, competition and facilitation through shared pollinators may be treated as a continuum, rather than two exclusive categories (Sargent \& Ackerly 2008). Thus, several hummingbirdpollinated species co-occurring in the Atlantic rainforest show differences in flowering phenology and morphology, fact that make them unique to test the prevalence of this process (Machado \& Semir 2006; Vizentin-Bugoni et al. 2014). Associated with measurements of fitness, future studies may help understanding the outcomes regarding plant interference when sharing pollinators (Wolowski et al. 2013).

\section{Acknowledgement}

MS is grateful to CNPq, for the PQ 1A Grant. Authors thanks Raoni Rebouças by the draws of Figure 1.

\section{References}

Aizen, M.A. \& Vázquez, D.P. 2006. Flowering phenologies of hummingbird plants from the temperate forest of southern South America: is there evidence of competitive displacement? Ecography 29: 357-366.
Almeida, E.M. \& Alves, M.A. 2000. Fenologia de Psychotria nuda e P. brasiliensis (Rubiaceae) em uma área de floresta Atlântica no sudeste do Brasil. Acta Botanica Brasilica 14: 355-346.

Almeida, E.M. 2005. Ecologia reprodutiva e comportamento dos visitantes florais e dos frugívoros em duas espécies de Psychotria L. (Rubiaceae) em uma área de floresta Atlântica, Ilha Grande, Rio de Janeiro. Tese de Doutorado. Universidade do Estado do Rio de Janeiro, Rio de Janeiro. 227p.

Amaya-Márquez; M. Stiles, F.G. \& Rangel-Ch, J.O. 2001. Interacción planta-colibrí en Amaycacu (Amazonas, Colombia): una perspectiva palinológica. Caldasia 23: 301-322.

Araújo, F.P. 2010. A comunidade de plantas ornitófilas da Estação Ecológica do Panga: o fluxo de pólen intermediado pelo beija-flor Phaethornis petrei (Phaethornithinae). Tese de doutorado. Universidade Estadual de Campinas, Campinas. 147p.

Ashman, T-L. \& Arceo-Gómez, G. 2013. Toward a predictive understanding of the fitness costs of heterospecific pollen receipt and its importance in co-flowering communities. American Journal of Botany 100: 1061-1070.

Borgella Jr.R.; Snow, A.A. \& Gavin, T.A. 2001. Species richness and pollen loads of hummingbirds using forest fragments in southern Costa Rica. Biotropica 33: 90-109.

Brown, J.B. \& Mitchell, R.J. 2001. Competition for pollination: effects of pollen of na invasive plant on seed set of a native congener. Oecologia 129:43-49.

Brown, J.H. \& Kodric-Brown, A. 1979. Convergence, competition, and mimicry in a temperate community of hummingbird-pollinated flowers. Ecology 60: 1022-1035.

Buzato, S.; Sazima, M. \& Sazima, I. 2000. Hummingbirdpollinated floras at three atlantic forest sites. Biotropica 32: 824-841.

Canela, M.B.F. \& Sazima, M. 2003. Aechmea pectinata: a hummingbird-dependent Bromeliad with incospicuous flowers from the rainforest in Southeastern Brazil. Annals of Botany 92: 731-737.

Castro, C.C. \& Araújo, A.C. 2004. Distyly and sequential pollinators of Psychotria nuda (Rubiaceae) in the atlantic rain forest, Brazil. Plant Systematics and Evolution 244: 131-139.

Corrêa, C.E. 2011. Ecologia de populações de Psychotria nuda (Rubiaceae) em Floresta Ombrófila Densa. Tese de Doutorado. Universidade Estadual de Campinas, Campinas. 118p.

Feinsinger, P. \& Tiebout H.R. 1991. Competition among plants sharing hummingbird pollinators: laboratory experiments on a mechanism. Ecology 72: 19461952. 
Feinsinger, P.; Busby, W.H. \& Tiebout III, H.M. 1988. Effects of indiscriminate foraging by tropical hummingbirds on pollination and plant reproductive success: experiments with two tropical treelets (Rubiaceae). Oecologia 76: 471474.

Galen, C. \& Gregory, T. 1989. Interespecific pollen transfer as a mechanism of competition: consequences of foreign pollen contamination for seed set in the alpine midflower, Polemonium viscosum. Oecologia 81: 120-123.

Henderson, J.; Hurly, T.A. \& Healy, S.D. 2001. Rufous hummingbird's memory for flower location. Behaviour, 61: 981-986.

Jakobsson, A.; Padrón, B. \& Traveset, A. Pollen transfer from invasive Carpobrotus spp. to natives - a study of pollinator behaviour and reproduction success. Biological Conservation 141: 136-145.

Justino, D.G.; Maruyama, P.K. \& Oliveira, P.E. 2012. Floral resource availability and hummingbird terriotiral behaviour on a Neotropical savanna shrub. Journal of Ornitholoy 153: 189-197.

Kearns, C.A. \& Inouye, D.W. 1993. Techniques for pollination biologists. University Press of Colorado, Boulder. 583p.

Lasprilla, L.R. 2003. Interações planta/beija-flor em três comunidades vegetais da parte sul do Parque Nacional Natural Chiribiquete, Amazonas (Colômbia). Tese de Doutorado. Universidade Estadual de Campinas, Campinas. 123p.

Leme, E.M.C. 1998. Canistropsis - Bromélias da Mata Atlântica/Bromeliads of the Atlantica forest. Salamandra, Rio de Janeiro. 143p.

Machado, C.G. \& Semir, J. 2006. Fenologia da floração e biologia floral de bromeliáceas ornitófilas de uma área da Mata Atlântica do Sudeste brasileiro. Revista Brasileira de Botânica 29: 163-174.

Mitchell, R.J.; Flanagan, F.J.; Brown, B.J.; Waser, N.M. \& Karron, J.D. 2009. New frontiers in competition for pollination. Annals of Botany 103: 1403-1413.

Moragues, E. \& Traveset, A. 2005. Effect of Carpobrotus spp. on the pollination success of native plant species of the Balearic Islands. Biological Conservation 122: 611-619.

Morales, C.L. \& Traveset, A. 2008. Interespecific pollen transfer: magnitude, prevalence and consequences for plant fitness. Critical Reviews in Plant Sciences 27: 221-238.

Ramírez, S.R.; Eltz, T.; Fujiwara, M.K.; Gerlach, G.; Goldman-Huertas, B.; Tsutsui, N.D. \& Sanches, N.E. 2011. Asynchronous Diversification in a Specialized Plant-Pollinator Mutualism. Science 333: 1742-1746.

Rech, A.R. \& Westerkamp, C. 2014. Biologia da Polinização: uma síntese histórica. In : Rech, A.R.; Agostini, K.; Oliveira, P.E.G.M. \& Machado,
I.C.S. Biologia da Polinização. Editora Projeto Cultural, Rio de Janeiro. 527p.

Rocca-de-Andrade, M.A. 2006. Recurso floral para aves em uma comunidade de Mata Atlântica de encosta: sazonalidade e distribuição vertical. Tese de Doutorado. Universidade Estadual de Campinas, Campinas. 118p.

Rodriguez-Flores, C.I. \& Stiles, F.G. 2005. Análises ecomorfológico de una comunidad de colibríes ermitaños (Trochilidae, Phaethorninae) y sus flores en la Amazonia Colombiana. Ornitología Colombiana 3: 7-27.

Sanchez, M.; Pedroni, F.; Leitão Filho, H.F. \& Cesar, O. 1999. Composição florística de um trecho de floresta ripária na Mata Atlântica em Picinguaba, Ubatuba, SP. Revista Brasileira de Botânica 22: 31-42.

Sargent, R.D. \& Ackerly, D.D. 2008. Plantpollinator interactions and the assembly of plant communities. Trends in Ecology and Evolution 23: $123-130$.

Sazima, I.; Buzato, S. \& Sazima, M. 1995. The sawbilled hermit Ramphodon naevius and its flowers in southeastern Brazil. Journal für Ornithologie 136: 195-206.

Sazima, I.; Buzato, S. \& Sazima, M. 1996. An assemblage of hummingbird-pollinated flowers in a montane forest in southeastern Brazil. Botanica Acta 109: 149-160.

Sigrist, T. 2007. Guia de Campo: aves do Brasil Oriental. Avis Brasilis, São Paulo. 448p.

Soares, N.C. 2011. Variação intra-específica na fenologia de espécies de sub-bosque de Floresta Atlântica e sua relação com variáveis microambientais. Dissertação de Mestrado. Universidade Estadual Paulista Júlio de Mesquita Filho, São Paulo. 66p.

Stiles, F.G. 1977. Coadapted competitors: the flowering seasons of hummingbird-pollinated plants in a tropical rainforest. Science 198: 1177-1178.

Veloso, H.P. \& Góes-Filho, L. 1982. Fitogeografia Brasileira: classificação fisionômico-ecológica da vegetação neotropical. Boletim Técnico do Projeto RADAM BRASIL. Série Vegetação n1. Ministério das Minas e Energia, Salvador. 86p.

Vervaeke, I.; Parton, E.; Maene, L.; Deroose, R. \& De Proft, M.P. 2001. Prefertilization barriers between different Bromeliaceae. Euphytica 118: 91-97.

Vizentin-Bugoni, J.; Maruyama, P.K. \& Sazima, M. 2014. Process entangling interactions in communities: forbidden links are more important than neutrality in a hummingbird-plant network. Proceedings of the Royal Society London B, Biological Sciences 281: 20132397.

Waser, N.M. \& Ollerton J. (eds.). 2006. Plantpollinator interactions: from specialization to 
generalization. The University of Chicago Press, Chicago. 488p.

Wendt, T.; Coser, T.S.; Matallana, G. \& Guilherme, F.A.G. 2008. An apparent lack of prezygotic reproductive isolation among 42 sympatric species of Bromeliaceae in southeastern Brazil. Plant systematic and evolution 175: 31-41.
Willmer, P. 2011. Pollination and floral ecology. Princenton University Press, New Jersey. 778p.

Wolowski, M.; Ashman, T-L. \& Freitas, L. 2013. Community-wide assessment of pollen limitation in hummingbird-pollinated plants of a tropical montane rain forest. Annals of Botany 112: 903-910. 